\title{
Responsibilities of E-Commerce Platform Providers Against Copyright Infringement in Indonesia: Comparison with Singapore
}

\author{
Anggara Hendra Setya Ali ${ }^{1}$, OK. Saidin ${ }^{2}$, Kholis Roisah ${ }^{3}$, Edi Warman ${ }^{4}$
}

\author{
${ }^{1,2,4}$ Doctor of Law Program, Universitas Sumatera Uatara, Medan, North Sumatra, Indonesia \\ ${ }^{3}$ Doctor of Law Program, Universitas Diponegoro, Semarang, Middle Java, Indonesia \\ Email: anggarahsa@yahoo.com, Saidin@usu.ac.id, r.kholis@yahoo.com,ediwarman@yahoo.com
}

\begin{abstract}
The advancement of technology through the development of the internet has changed of society on a global scale, especially in the trade sector. Conventional businesses have shifted to online or e-commerce platforms. However, pirated goods have also made their way to these platforms. It would be unfair to hold merchants as the sole responsible party accountable for copyright infringements. Therefore, e-commerce platforms were also made liable. E-commerce platforms should be informed on the extent of their responsibilities regarding copyright infringement to ensure legal certainty and justice in conducting digital business. This research analyzes the responsibilities of ecommerce platforms as internet intermediaries regarding copyright infringement in Indonesia and provides comparisons with Singapore. This study is normative research that was analyzed qualitatively using a descriptive method. Although the legal system of Indonesia and Singapore differ, the results show many similarities regarding the responsibilities of e-commerce platforms as internet intermediaries in copyright infringements.
\end{abstract}

Keywords: Responsibility, E-Commerce, Copyright

\section{INTRODUCTION}

The development of technology through the internet has transformed all aspects of human life, including the trade sector. [1] Conventional businesses have shifted to online or e-commerce platforms to take advantage of the global network provided by the internet. [2] The "We Are Social" survey in April 2021 shows that our country has one of the biggest e-commerce usage rates. [3] The people of Indonesia actively use several unicorn-level platforms, such as Tokopedia with 135 million visits/month and Shopee with 127.4 million visits/month. [4]

These facts show that e-commerce plays a crucial role in Indonesian trade traffic. However, e-commerce platforms utilize the internet to conduct transactions and are thus prone to intellectual property infringements, especially copyright. [5] For example, a famous novelist has recently stated in his social media account that wellknown e-commerce platforms in Indonesia enable the circulation of the pirated versions of his novels. The novels are sold very cheaply, ranging from IDR20,000 (twenty thousand rupiahs) up to IDR30,000 (thirty thousand rupiahs). [6]
Book piracy is detrimental not only to book authors as legitimate copyright owners but also to consumers. Pirated products are often of lower quality and unoriginal, and there are even cases of these products becoming health hazards due to not following standards. Therefore, e-commerce merchants should take action to stop piracy on the platforms that they use.

Indonesia Copyright Act states that works that exist on or are affiliated through the internet are protected. In addition, Electronic Information and Transactions Act (EIT Act) also states that intellectual property rights must protect works that exist on the internet. However, neither the Copyright Act nor the EIT Act has specifically regulated the accountability of e-commerce platforms regarding the content or service system that infringes copyright. The vagueness of these regulations can also create legal uncertainty for ecommerce merchants.

In addition to the two above Acts, Law 7 of 2014 Regarding Trade (Trade Act) also states that every business actor who trades goods and services using an electronic system must provide complete and correct data and information. However, neither the Copyright 
Act, the EIT Act, and the Trade Act specifically regulate the legal responsibilities of e-commerce platforms. These Acts only regulate electronic system operators in general.

E-commerce platforms are considered internet intermediaries, which are platforms that facilitate buying and selling while not owning the goods themselves. [7] Currently, several countries have specific rules regarding the responsibility of internet intermediaries for copyright infringement, such as America and members of the European Union. [8] This problem has also reached African countries such as Kenya, Morocco, and Tanzania. [9]

The lack of regulations on the responsibilities of e-commerce platforms regarding copyright infringements in Indonesia has negatively impacted copyright protection efforts in e-commerce. Copyright holders must still independently monitor the goods sold through e-commerce platforms.

\section{RESEARCH METHOD}

This research uses a normative legal method to explain the principles of law, vertical and horizontal synchronization, and comparisons between legal systems. [10]

Comparisons were made by reviewing and comparing the legislation and implementation of internet intermediary responsibilities in Singapore, which has a different legal system from Indonesia.

With online access to various regulations and academic articles from different legal systems, it is possible to compare the enforcement of a rule to determine how other countries face similar problems, which we may also face. [11]

\section{RESULTS AND DISCUSSION}

\subsection{Liabilities of E-commerce Platforms}

All regulations related with electronic system require operators to work reliably and safely to ensure that the electronic system operates appropriately. As internet intermediaries, e-commerce platforms are accountable for transactions that occur on the platform. These platforms have terms of use or license agreements that require users to use the platform following the applicable laws and regulations. In addition, these platforms possess technology control or means of receiving reports or complaints regarding pirated content. However, the terms of use do not eliminate the responsibility of the e-commerce platform to control copyright infringements.

Based on the internet intermediary liability doctrine, copyright protection can be grouped into three, namely: [12]

\subsubsection{Strict Liability}

Under the strict liability doctrine, e-commerce platforms are responsible for third-party content whether or not there is prior knowledge on the legality of the content. The only way to avoid liability in such circumstances is to proactively monitor, filter, and remove content that may infringe copyright. Even so, the e-commerce platform is still accountable for omissions of infringing content. The strict liability model heavily burdens e-commerce platforms. This model exists in only a few jurisdictions and is implemented in specific areas of the law.

\subsubsection{Broad Immunity}

Under the broad immunity liability doctrine, ecommerce platforms as internet intermediaries are not liable for certain third-party content. However, this exemption is only valid for certain legal subjects. If the subjects are not limited, e-commerce platforms can profit or even conspire with the piracy actors. This situation is detrimental to the public and the rule of law. There has been much discussion on this model at the international level seeking to establish general principles and best practices. For example, the OECD Council included the intermediary internet liability limitation in December 2011 as one of the recommended principles for internet policymaking to promote and protect the free global flow of digital information. Another initiative is The Manila Principles on internet intermediary liability, proposed by scholars and civil society organizations in February 2015. One of the basic principles is the legal protection of internet intermediaries from liability for third-party content. [13]

\subsubsection{Conditional liability}

The conditional liability doctrine is the most widely used doctrine to regulate the responsibilities of $\mathrm{e}$ commerce platforms as internet intermediaries. In this doctrine, internet intermediaries are free from accountability for third-party content if they meet certain conditions and vice versa. In contrast to the strict liability model, conditional liability does not demand internet intermediaries to proactively monitor and filter content. In this model, liability depends on the involvement and knowledge of intermediaries regarding third-party content and the nature of the related content infringement.

In this doctrine, there is an important mechanism known as the safe harbor. In Indonesia, Article 22 Paragraph (2) of Government Regulation Number 80 of 2019 concerning Trading Through Electronic Systems regulates the safe harbor policy. The safe harbor policy is a government policy that separates the responsibilities of e-commerce platforms from merchants who use their services. Article 22 Paragraph (2) states that the provisions in Paragraph (1) above do not apply if the electronic system operator removes electronic links and illegal electronic information 
content immediately after obtaining knowledge or awareness of its existence.

However, according to the author, e-commerce platforms can still be held responsible regardless of the safe harbor policy if they have intentionally ignored the existence of products on their platform that infringes copyright. E-commerce platforms may also be subject to both criminal and civil liability.

\subsubsection{Criminal Liability}

In the realm of criminal law, e-commerce platforms can be held responsible through the concept of participation, namely as an accomplice or medeplichtige, especially before a crime is committed by providing opportunities, facilities, or information. This situation is similar to provocation (uitlokking), the difference being the intention or will. Criminal intent is not caused by an accomplice, while provocation creates such intent. [14]

Article 57 Paragraph (1) of the Criminal Code states that accomplices face two-thirds of the maximum sentence.

The criminal sentences contained in the Copyright Law include Article 113, with a prison sentence from 1 (one) to 10 (ten) years and a fine from 100 million to 4 billion rupiahs. According to the author, internet intermediaries that facilitate usergenerated content (UGC) such as e-commerce platforms can also be subject to Article 114 of the Copyright Law. The Article does not specify the nature of the marketplace, whether it is conventional or digital. The business actor faces a maximum fine of 100 million rupiahs.

In conjunction with Law Number 19 of 2016 concerning Electronic Information and Transactions (EIT Law), Law Number 11 of 2008 defines copyright as an electronic document that must be protected. Therefore, e-commerce platforms can also be held accountable. Article 15 Paragraph (2) also confirms the accountability of e-commerce platforms. The Article states that "the electronic system operator is responsible for the operations of the electronic system." The EIT Law regulates criminal sentences regarding online copyright infringements through Article 32 Paragraph (1) and (2) Jo Article 48 Paragraph (1) and (2) of the EIT Law. The criminal faces 8 to 9 years of imprisonment with a fine of 2 to 3 billion rupiahs.

Based on the Copyright Law and the EIT Law, e-commerce platforms are criminally liable if deemed to have assisted in copyright infringement. However, Article 95 Paragraph (4) of the Copyright Law states that alternative dispute resolution must first be sought through mediation before making criminal charges.

b. Civil Liability

Civil liability can be divided into 2 (two), namely: (a) liability due to an agreement/contractual relationship (privity of contract), and (b) liability due to law. Furthermore, the responsibilities that arise from laws include (i) responsibilities that arise solely because of the law or (ii) responsibilities that arise due to the actions of others.

According to the author, e-commerce platforms may be charged with copyright infringement participation as regulated in Article 99 of the Copyright Law even though their users committed the infringement.

Article 1365 of the Civil Code states that elements of error include all levels of error from intentional to negligent [15] as contained in Article 1366 of the Civil Code. Therefore, e-commerce platforms that fail to take preventive steps or respond to notifications on copyright infringement can be held accountable for the losses. Following this, the author, copyright holder, or related rights owner may file a lawsuit to the commercial court.

\subsection{Regulations on Internet Intermediary Liability in Singapore}

The common law and civil law systems have distinct differences in various aspects, such as historical heritage and origins, sources, professions, and education. However, there are also some similarities: both systems handle various aspects of legal issues. For this reason, the author tries to compare the different legal systems of Indonesia and Singapore.

The author chose Singapore as it is a neighboring country with a common law system inherited from the UK. However, the parliament of Singapore has enacted the Application of English Law Act (AELA) in 1993, which seeks to filter British law according to the conditions and needs of the people of Singapore. [16]

Singapore is one of the countries in the SEA region which limits the liability of internet intermediaries for online copyright infringements. Article 10 of the Electronic Transactions Act 1998 states that a network service provider will not be subject to civil or criminal liability under the law regarding digital material owned by a third party if it only serves as an access provider for:

- The creation, publication, or distribution of such materials or any statements made in such materials; or

- Violation of any rights that are part of or in connection with the material.

However, the provisions in Article 10 of the Electronic Transactions Act 1998 do not apply to copyright infringements that occur on electronic media as stated in Article 10 Paragraph (2) letter d of the Electronic Transactions Act 1998. Online copyright infringements are regulated separately through the Singapore Copyright Act (Chapter 63). 
According to the Singapore Copyright Act, network service providers are not liable for copyright infringements while carrying out their integral functions, including transmissions, routing and connection provision, system caching and storage, and obtaining location information. However, the internet intermediary must also meet the requirements and obligations to be immune from claims of copyright infringement. These requirements include:

- The transmission of the copyrighted content was initiated by another party and not by the internet intermediary;

- Transmissions, routing and connection provision, system caching and storage, and obtaining location information are carried out automatically without any selection process by the internet intermediary;

- The internet intermediary makes no substantive modifications (other than modifications made as part of a technical process) to the contents of the cached copy;

- The internet intermediary does not receive any financial benefit from copyright infringement.

In addition to the conditions above, internet intermediaries must immediately delete or restrict access to the content (notice and takedown) as soon as a report or notification of copyright infringement is received to be exempt from legal liability.

\section{CONCLUSION}

Based on the analysis above, Indonesian law does not yet regulate the responsibilities of e-commerce platforms in copyright infringements; only government regulations and ministerial circular letters have done so. However, as a member of the WTO and Trips, Indonesia has made efforts to adapt its laws to international standards. In addition, although the Indonesian legal system is different from Singapore, there are several similarities regarding the responsibilities of e-commerce platforms or internet intermediaries.

\section{ACKNOWLEDGMENTS}

The authors would like to thank all parties for all their supports in writing this paper. The authors would also like to express their highest gratitude to the Doctor of Law Program, Universitas Sumatera Utara, for providing facilities to present this paper at an international conference.

\section{REFERENCES}

[1] A. Marsoof and I. Gupta, "Shielding internet intermediaries from copyright liability-A comparative discourse on safe harbours in Singapore and India," J. World Intelect. Prop., vol. 22, no. 3-4, pp. 234-270, [Online] Available: https://doi.org/10.1111/jwip.12126.

[2] O.K. Saidin, Aspek Hukum Hak Kekayaan Intelektual (Intellectual Property Rights). Jakarta: Raja Grafindo Persada, 2004.

[3] "Penggunaan E-Commerce Indonesia Tertinggi di Dunia," 2021 https://databoks.katadata.co.id/datapublish/2021 /06/04/penggunaan-e-commerce-indonesiatertinggi-di-dunia\# (accessed Jun. 13, 2021).

"No

Title."

https://iprice.co.id/insights/mapofecommerce/ (accessed June 13, 2021).

[5] E. Djaja, Penyelesaian Sengketa Hukum Teknologi Informasi dan Transaksi Elektrik. Yogyakarta: Pustaka Timur, 2010.

[6] J. G. Rizal, "Ramai Tere Liye Kritik Buku Bajakan di E-commerce, Ini Kata Tokopedia dan Lazada." https://www.kompas.com/tren/read/2021/05/25/ 180000365/ramai-tere-liye-kritik-buku-bajakandi-e-commerce-ini-kata-tokopedia-dan?page =all (accessed June 13, 2021).

[7] K. Perset, "The Economic and Social Role of Internet Intermediaries," OECD Digit. Econ. Pap., vol. 171, no. 8 April, 2010, [Online]. Available:

https://doi.org/10.1787/5kmh79zzs8vb-en.

[8] M. L. Montagnani and A. Y. Trapova, "Safe harbours in deep waters: A new emerging liability regime for Internet intermediaries in the Digital Single Market," Int. J. Law Inf. Technol., vol. 26, no. 4, pp. 294-310, 2018, doi: 10.1093/ijlit/eay013.

[9] G. F. Frosio, "The Center for Internet and Society, World Intermediary Liability Map (WILMAP).” http://cyberlaw.stanford.edu/ourwork/projects/world-intermediary-liability-mapwilmap (accessed Mar. 18, 2021).

[10] Amirudin and Z. Asikin, Pengantar Metode Penelitian Hukum. Jakarta: Rajawali Press, 2004.

[11] M. Salter and J. Mason, Writing Law Dissertations. London: Pearson Education Limited, 2007.

[12] X. Hong, "Regulation of E-Commerce Intermediaries: An International Perspective, Trade Development Through Harmonization of Commercial Law," Hors Ser., vol. XIX, p. 369, 2015, [Online]. Available: https://www.wgtn.ac.nz/law/research/publicatio ns/about-nzacl/publications/special-issues/horsserie-volume-xvi,-2013/Hong.pdf.

[13] "A Global Civil Society Initiative, Manila 
Principles on Intermediary Liability: Best Practices Guidelines for Limiting Intermediary Liability for Content to Promote Freedom of Expression and Innovation," [Online]. Available:

https://www.eff.org/files/2015/10/31/manila_pri nciples_1.0.pdf.

[14] P. A. F. Lamintang, Dasar-dasar Hukum Pidana Indonesia. Bandung: Sinar Baru, 1990.

[15] A. K. Muhammad, Hukum Perdata Indonesia. Bandung: PT Citra Aditya Bakti, 2000.

[16] P. de Cruz, Comparative Law in a Changing World, London: Cavendish Publishing Limited, 1999, Translated by Narulita Yusron, Perbandingan Sistem Hukum Common Law, Civil Law, and Socialist Law, Bandung: Nusa Media, 2017 